\title{
SEKULARITAS DAN SPRITUALITAS; MENCARI FORMAT INTEGRASI ILMU UNTUK KONSTRUKSI KURIKULUM PENDIDIKAN ISLAM
}

\author{
Sopian Sinaga \\ Program Studi Pendidikan Bahasa Arab STAI As-Sunnah \\ Jl. Medan-Tj. Morawa, KM 13, Gg. Darmo, Desa Bangun Sari, Kab. D. Serdang, Sumut \\ abumuhammadsinaga@gmail.com
}

\begin{abstract}
Abstrak: Pendidikan Islam merupakan bagian dari ajaran Islam yang menjadi satu-satunya agama yang dijamin oleh Allah eksistensinya sampai kiamat. Karena itu, maka pendidikan Islam akan senantiasa relevan untuk dipakai kapanpun dan dimanapun ia berada. Ajaran Islam cakupannya sangat luas, pembahasannya mencakup semua lini kehidupan di masyarakat, karena itu Islam tidak dapat dipisahkan dari kehidupan manusia. Jika dalam masyarakat Barat adanya pemisahan agama dari kehidupan dunia, agama hanya ada di greja, maka hal itu tidak terjadi di umat Islam.

Ada aliran dan pemahaman sebagian manusia yang memisahkan antara agama dan kehidupan sosial di masyarakat yaitu ajaran sekuler sehingga muncul istilah sekularitas dan spritualitas. Orang-orang sekuler adalah orang yang meyakini keharusan adanya pemisahan antara urusan agama dan urusan keduniaan mencakup masalah politik, ekonomi, hukum, sosial-budaya serta ilmu pengetahuan dan teknologi. Sementara spritualitas adalah hal-hal yang berkaitan dengan kerohanian dan agama serta ketuhanan dan kehidupan akhirat. Adapun pandangan Islam terhadap sekularitas, maka dapat dikatakan bahwa ia bertentangan dengan ajaran Islam yang mengajarkan ilmu secara menyeluruh dan konprehensif. Sekularitas tidak sejalan dengan ajaran Islam bisa dilihat dari kenyataan, nash dan sejarah. Melihat kondisi umat Islam terutama di Indonesia pada khususnya, maka perlu kiranya dilakukan rekonstruksi kurikulum pendidikan Islam agar tujuan penciptaan manusia menjadi hamba Allah dengan misi menjadi khalifah di atas bumi bisa tercapai insya Allah.
\end{abstract}

Kata Kunci : Sekularitas, Spritualitas, Integrasi Ilmu, Kurikulum Pendidikan Islam

\section{A. Pendahuluan}

Bangsa Indonesia adalah bangsa yang besar. Mayoritas penduduknya adalah umat Islam. Namun bangsa besar yang umumnya muslim ini belum mampu menunjukkan kualitasnya baik dari sektor ekonomi, pendidikan, industri dan lain-lain. Justru kita hanya menjadi bangsa yang kaya dengar sumber daya alam dan manusianya namun menjadi jongos bagi orang lain. Sehingga nampaklah kemiskinan di mana-mana, kita hanya 
menjadi konsumen bagi produk bangsa lain, martabat bangsa ini di mata dunia hanya dipandang sebelah mata.

Kelemahan bangsa ini selain memang karena ada upaya pelemahan dari bangsa lain demi meraup keuntungan dari kita, juga adalah karena banyaknya persoalan internal dalam diri bangsa ini. Diantara penyebab terpuruknya kualitas bangsa ini adalah adanya dikotomi ilmu dan pemisahan antara agama dan ilmu pengetahuan atau sains. Seolah-olah agama tidak mengajarkan ilmu pengetahuan atau tidak bisa bersatu dengan ilmu pengetahuan dan teknologi. Sebaliknya seolah-olah jika ilmu pengetahuan bergandengan dengan agama, maka ia hanya akan mengakibatkan kemunduran sains itu sendiri. Padahal Islam realitanya sejalan dan sangat mendukung ilmu pengetahuan dan teknologi. Fakta sejarah juga sudah membuktikan bahwa Islam sudah membawa manusia dari masa gelap menuju jaman keemasan Islam yaitu sekitar abad 2-7 Hijriyah.

Melihat persoalan di atas ditambah dengan tantangan zaman yang terus bertambah, maka tidak ada tawar menawar kecuali merekonstruksi kurikulum pendidikan kita berdasarkan integrasi antara ilmu umum dengan ilmu agama. Karena kita meyakini bahwa agama Islam sejatinya tidak akan membawa manusia kecuali kepada masa kejayaan. Dengan demikian, kurikulum yang dipandang baik untuk mencapai tujuan pendidikan Islam adalah yang bersifat integrated dan komprehenshif, mencakup ilmu agama dan umum. Sehingga kurikulum tersebut jauh dari nilai-nilai sekularisme yang memisahkan antara agama dan kehidupan dunia, antara agama dan ekonomi, social dan politik. Kesempurnaan manusia tidak tercapai kecuali dengan menyerasikan antara ilmu agama dan ilmu pengetahuan. Yang demikian itulah yang dapat menjadikan umat ini dapat melahirkan pemikirpemikir hebat dan unggul di masanya seperti Ibnu Sina, Ibnu Rusyd, AlGhazali, Ibnu Khaldun dan lain-lain. 


\section{B. Pembahasan}

\section{Pengertian sekularitas dan Spritualitas}

Istilah Sekularisasi berakar dari kata Sekuler yang berasal dari bahasa latin Seaculum artinya abad (age, century), yang mengandung arti bersifat dunia, atau berkenaan dengan kehidupan dunia sekarang. Dalam bahasa Inggris kata secular berarti hal yang bersifat duniawi, fana, temporal, tidak bersifat spritual, abadi dan sakral serta kehidupan di luar biara. ${ }^{1}$ Dalam Kamus Besar Bahasa Indonesia, Sekularisasi diartikan segala hal-hal yang membawa ke arah kehidupan yang tak didasarkan pada ajaran agama. $^{2} \quad$ Sekuler adalah kata sifat yang menggambarkan suatu keadaan dimana ia telah memisahkan kehidupan duniawi dari pengaruh agama atau hal-hal yang berbau perihal spiritual. Sedangkan sekularisme adalah suatu paham yang ingin memisahkan atau menetralisir semua bidang kehidupan seperti politik dan keanekaragaman, ekonomi, hukum, sosial-budaya dan ilmu pengetahuan teknologi dari pengaruh agama atau hal-hal yang ghaib. ${ }^{3}$ Sekularisasi sering diartikan sebagai pemisahan antara urusan Negara (politik) dan urusan agama atau pemisahan antara urusan duniawi dan ukhrawi (akhirat). ${ }^{4}$

Adapun spritualitas menurut KBBI adalah berhubungan dengan atau bersifat kejiwaan (rohani, batin).5 Dalam bahasa Indonesia spiritual diartikan sebagai segala sesuatu yang berhubungan dengan kejiwaan (rohani atau batin). Lebih lanjut spiritualism disebut sebagai aliran filsafat yang mengutamakan kerohanian. Kata spiritualitas diturunkan dari kata spirituality, yang dalam bahasa Inggris dimaknai sebagai kualitas manusia yang berhubungan dengan persoalan-persoalan spiritual. ${ }^{6}$

\footnotetext{
${ }^{1}$ Juhaya S. Praja, Aliran-Aliran Filsafat dan Etika, (Bogor: Kencana, 2003), h. 188.

2 Tim Penyusun Kamus Pustaka Bahasa, Kamus Besar Bahasa Indonesia, (Jakarta: Balai Pustaka, 2002), h. 101.

3 M.Tahir,Negara Hukum Suatu Tentang Prinsip-prinsipnya Dilihat dari Segi Hukum Islam, Implementasinya pada Periode Negara Madinah dan Masa Kini , (Jakarta:Kencana Prenada Media Group, 2007 cet. Ke-3), h. 19.

${ }^{4}$ Pardoyo,.Sekularisasi Dalam Polemik, 1993, h. 19.

${ }^{5}$ https://kbbi.web.id/spiritual, diakses pada 16 Desember 2017.

${ }^{6}$ Amin Syukur, Sufi Healing, Terapi dengan Model Tasawuf, (Jakarta : Erlangga, 2012), h.
} 43. 
Dari beberapa pengertian di atas, maka dapat disimpulkan bahwa sekularitas adalah pemisahan antara urusan agama dan urusan keduniaan mencakup masalah politik, ekonomi, hukum, sosial-budaya serta ilmu pengetahuan dan teknologi. Sementara spritualitas adalah hal-hal yang berkaitan dengan kerohanian dan agama serta ketuhanan dan kehidupan akhirat.

\section{Sekularitas dan Spritualitas dalam Islam}

\section{a. Latar Belakang Lahirnya Sekularitas}

Sekularitas berasal dari dunia barat kristiani, yang muncul dengan diserukan oleh para pemikir bebas agar mereka terlepas dari ikatan gereja, para pemuka agama dan pendetanya. Pada awalnya agama Kristiani lahir di dunia Timur, namun warna Kristiani amat tebal menyelimuti kehidupan dunia Barat. Keadaan ini sejak kekaisaran Romawi Konstantin yang agung (280-337) yang melegalisasikan dalam dalam wilayah imperiumnya serta mendorong penyebarannya merata ke benua Eropa, terutama di abad pertengahan warna Kristiani meyelimuti kehidupan Barat baik politik, ekonomi, sosial, budaya, serta ilmu pengetahuan. ${ }^{7}$

Seruan untuk terlepas dari ikatan gereja, para pemuka agama Kristen dan pendetanya sebagaimana menurut Syekh Safar Hawali adalah karena kezaliman-kezaliman yang dilakukan pihak greja terhadap umatnya. Juga karena greja tidak sejalan dengan perkembangan ilmu pengetahuan, serta revolusi Perancis dan teori evolusi. $^{8}$

\section{b. Sekularitas Menurut Islam}

Berdasarkan pengertian sekularitas yang telah dijelaskan sebelumnya, maka kita dapat melihat bahwa ia bertentangan dengan ajaran Islam yang mengajarkan ilmu secara menyeluruh dan

\footnotetext{
${ }^{7}$ Nihaya, Filsafat Umum : dari Yunani sampai Modern, (Makassar: Berkah Utami,
} 1999), h. 12

${ }^{8}$ Safar Hawali, al-'Ilmaniyah, (Mekah: Daru Makkah, 1982), h. 123. 
konprehensif. Hal ini telah ditegaskan dalam Seminar Pendidikan Islam Internasional di Nigeria tahun 1977 yang telah menolak adanya sekularisasi dalam pendidikan Islam. ${ }^{9}$

Sekularitas tidak sejalan dengan ajaran Islam bisa dilihat dari kenyataan, nash dan sejarah.

1) Secara realitas dan kenyataan

Secara kenyataan Islam kita dapati mengajarkan masalah akidah, ibadah, akhlak, muamalah dan Islam juga mengajarkan masalah sosial ekonomi, politik, hukum dan lain sebagainya. Islam mengurus masalah dunia dan akhirat, jasmani dan rohani, lahir dan batin. Al-Qur'an sebagai sumber hukum utama dalam Islam, selain berisi ayat-ayat tentang ilmu-ilmu agama juga berisi ayat-ayat tentang ilmu umum temasuk konsep-konsep dalam matematika, sebagai contoh Q.S. 35:1, 37:147,18:25, 29:14, dan lain lain. Al-qur'an juga memuat tentang metode pengembangan ilmu pengetahuan termasuk ilmu matematika, sebagai contoh Q.S. 2:31 (definisi) dan Q.S. 6: 74-79 (riset). Selanjutnya mengenai perintah untuk melakukan penelitian (suatu kegiatan yang penting di dalam pengembangan sains), secara umum dapat dilihat antara lain dalam firman-Nya pada surat Yunus, ayat ke-101 "Katakanlah Muhammad: lakukanlah nadzor (penelitian dengan menggunakan metode ilmiah) mengenai apa-apa yang ada di langit dan bumi.

Perintah lebih khusus terdapat dalam surat al-Ghosiyah, ayat ke-17-20 yang artinya: "Apakah mereka tidak memperhatikan onta, bagaimana ia diciptakan. Dan langit, bagaimana ia ditinggikan. Dan gunung, bagaimana ia ditancapkan. Dan bumibagaimana ia dihamparkan". Ayat-ayat tersebut merupakan ayat-ayat metode ilmiah, yang memerintahkan kepada umat manusia untuk selalu meneliti. Kegiatan penelitian yang mencakup pengamatan, pengukuran, dan analisa data telah membawa perubahan besar dalam

\footnotetext{
${ }^{9}$ Abdurrahman Saleh Abdullah, Teori-Teori Pendidikan Berdasarkan Al-Qur'an, (Jakarta: PT Rineka Cipta, 2007), h. 165.
} 
dunia ilmu pengetahuan dan teknologi termasuk ilmu matematika. "niscaya Allah akan meninggikan orangorang yang beriman di antaramu dan orang-orang yang diberi ilmu pengetahuan beberapa derajat. dan Allah Maha mengetahui apa yang kamu amalkan”. (Q.S. Al Mujadilah : 11)

2) Secara nash dan dalil syar'i

Adapun secara nash, maka kita mendapati banyak nash yang mennjukkan bahwa Ajaran Islam itu lengkap dan menyeluruh, tidak memisahkan antara masalah agama dan ilmu pengetahuan, tidak memisahkan antara urusan dunia dan akhirat. Allah swt. berfirman: "Pada hari ini telah kusempurnakan bagi kalian agama kalian...". ${ }^{10}$ Allah swt. juga berfirman:

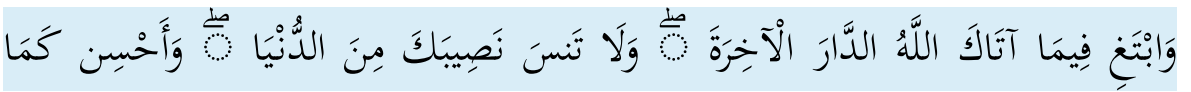

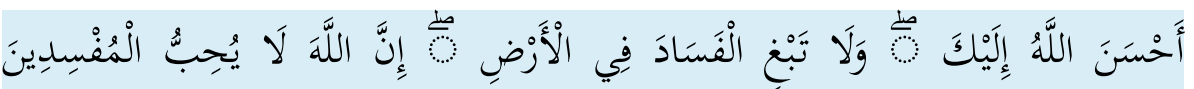

Artinya "Dan carilah pada apa yang telah dianugerahkan Allah kepadamu (kebahagiaan) negeri akhirat, dan janganlah kamu melupakan bahagianmu dari (kenikmatan) duniawi dan berbuat baiklah (kepada orang lain) sebagaimana Allah telah berbuat baik, kepadamu, dan janganlah kamu berbuat kerusakan di (muka) bumi. Sesungguhnya Allah tidak menyukai orang-orang yang berbuat kerusakan". ${ }^{11}$

Rasulullah saw. bersabda:

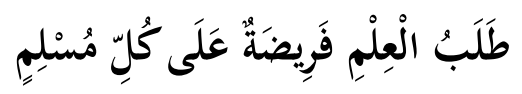

\footnotetext{
10 QS. Al-Maidah: 3.

${ }^{11}$ QS. Al-Qashash: 77.
} 


\section{"Menuntut ilmu itu wajib atas setiap muslim". ${ }^{12}$}

Pertanyaannya adalah ilmu apa yang perlu dicari? Tentunya keumuman hadis di atas menunjukkan bahwa semua ilmu yang bermanfaat harus dipelajari dan semua ilmu yang memberi manfaat dan maslahat untuk kehidupan manusia harus dicari serta dikuasai. Sebagaimana doa Rasulullah saw. yang menyebutkan bahwa beliau meminta perlindungan kepada Allah dari ilmu yang tidak bermanfaat. Hadis tersebut adalah:

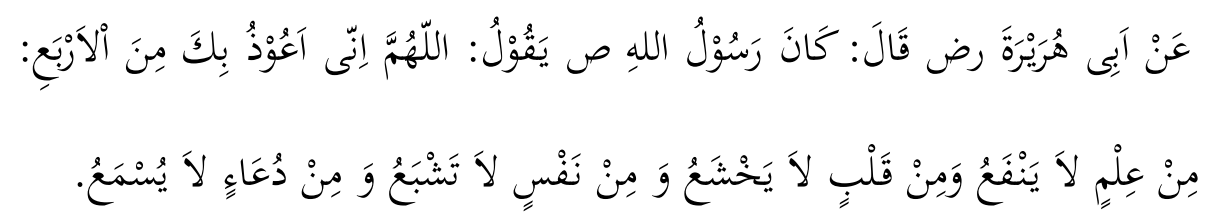

Dari Abu Hurairah RA, ia berkata : Adalah Rasulullah SAW bersabda, "Ya Allah, sesungguhnya aku berlindung kepadamu dari empat perkara. Dari ilmu yang tidak bermanfaat, dari hati yang tidak khusyu' dari jiwa yang tidak pernah kenyang dan dari doa yang tidak dikabulkan)". ${ }^{13}$

Inilah sebenarnya area, materi dan kontent dalam pendidikan islam yang sesuai dengan Al-Qur'an dan hadis. Tidak ada dikotomi ilmu dalam pendidikan islam, semisal ilmu umum dengan ilmu agama, ilmu dunia maupun ilmu akhirat. Lebih jauh lagi terkait dengan ilmu dan agama, sungguh luar biasa ungkapan Einstein seorang fisikawan modern yang secara normatif non-islam tapi dengan lantang berkata : "Religion without science is lame, but science without religion is blind" (agama tanpa ilmu adalah pincang, tapi ilmu tanpa agama adalah buta). ${ }^{14}$

3) Fakta sejarah

Berdasarkan sejarah peradaban Islam, jelas sekali kita mendapati bahwa Islam pernah menguasai 2/3 belahan bumi adalah karena umat Islam mengamalkan seluruh ajaran Islam tanpa

\footnotetext{
${ }^{12}$ HR. Ibnu Majah. Dinilai shahih oleh Syaikh Albani dalam Shahih wa Dha'if Sunan Ibnu Majah no. 224.

${ }^{13}$ HR. Abu Dawud, di dalam kitab Shalat, bab Isti'adzah

${ }^{14}$ Syamsul Ma'arif, Revitalisasi Pendidikan Islam, (Yogyakarta : Graha Ilmu, 2007), h. 33.
} 
memisahkan urusan dunia dari urusan agama, tanpa memisahkan antara agama dan ilmu pengetahuan. Di masa itulah banyak muncul ulama dan cendikiawan muslim terkenal seperti Ibnu Sina, Ibnu Khaldun, Ibnu Rusyd, al-Ghazali dan lain-lain.

\section{Pengembangan Kurikulum}

\section{a. Pengertian Kurikulum}

Dunia pendidikan biasa mendengar istilah kurikulum, namun apakah arti kurikulum itu sendiri? Berikut ini beberapa arti kurikulum yang disampaikan para ahli, yaitu:

1) Menurut Caswel dan Camp Bell dalam buku curriculum development, to be composed of all the eksperi-ences children have under the guid dance of teacher. Pada hakikatnya, kurikulum bukan hanya mata pelajaran rencana pembelajaran, melainkan pengalaman siswa, guru, dan semua yang ikut melaksanakan pendidikan, baik yang diperoleh didalam kelas maupun diluar kelas. $^{15}$

2) Abuddin Nata mengartikan kurikulum sebagai bahan pengajaran yang terangkum pada sejumlah mata pelajaran yang harus dipelajari sampai selesai/tamat dari suatu unit pendidikan dengan bukti mendapatkan suatu gelar, pengakuan ataupun ijazah. ${ }^{16}$

3) Menurut Ahmad tafsir, kurikulum minimal memiliki tiga pengertian, yaitu kurikulum dalam arti sejumlah mata pelajaran pada suatu jenjang unit pendidikan, kurikulum dalam arti silabus, dan kurikulum dalam arti program sekolah. Pengertian kurikulum yang terakhir inilah yang paling luas. ${ }^{17}$

4) Dalam literatur pendidikan Islam, istilah kurikulum dikenal dengan kata manhaj, jamaknya, manahij. Bila dikaitkan dengan pendidikan, maka manhaj adalah jalan terang yang dilalui pendidik

\footnotetext{
${ }^{15}$ Hamdani Hamid, Pengembangan Kurikulum Pendidikan, (Bandung : Pustaka Setia, 2012), h. 15-16.

${ }^{16}$ Abuddin Nata, Filsafat Pendidikan Islam (Jakarta: Logos Wacana Ilmu, 1997), h. 123.

${ }^{17}$ Ahmad Tafsir, Filsafat Pendidikan Islami: Integrasi Jasmani, Rohani dan Kalbu Memanusiakan Manusia (Bandung: Remaja Rosdakarya, 2006), h. 102-103.
} 
dengan anak didik untuk mengambangkan pengetahuan, keterampilan, dan sikap mereka. ${ }^{18}$

Dari beberapa pengertian ini dapat kita simpulkan bahwa kurikulum adalah semua yang diajarkan kepada peserta didik baik di dalam kelas maupun di luar kelas untuk menyampaikan peserta didik kepada kompetensi yang diharapkan.

\section{b. Kurikulum Pendidikan Islam Terintegrasi}

Belakangan ini, muncul banyak tuntutan agar pendekatan studi islam dan sains tidak didikotomikan dalam mengkaji islam, tetapi diintegrasikan. Karena pada prinsipnya, sesuai dengan ajaran AlQur'an, Islam memang tidak mengenal dikotomi antara agama dan ilmu (sains), jasmani dan rohani, rasio dan empiris, dunia dan akhirat. Gagasan tentang integrasi ilmu pengetahuan agama dan ilmu pengetahuan umum bukan merupakan fenomena baru dalam khazanah epistemologi keilmuan Islam. Pada era golden age (masa keemasan) Islam periode Abbasiyah, kedua ilmu pengetahuan ini tetap terintegrasi hingga kemudian di buyarkan oleh redupnya dinamika peradaban Islam menyusul terjadinya spesialisasi ilmu pengetahuan modern yang bersembnyi di balik politik kolonialisasi dan imperialisasi dunia Islam.

Paradigma integrasi ilmu berarti cara pandang tertentu atau model pendekatan tertentu terhadap ilmu pengetahuan yang bersifat menyatukan, disebut paradigma integrasi ilmu integratif atau singkatnya paradigma integrasi ilmu integralistik yaitu pandangan yang melihat sesuatu ilmu sebagai bagian dari keseluruhan. ${ }^{19}$

Dalam konteks Indonesia, usaha integrasi ilmu-ilmu agama dan ilmu-ilmu umum pernah dilakukan oleh M. Natsir sebagaimana tertuangkan dalam buku Capita Selecta. Menurut Natsir, pendidikan islam yang integral tidak mengenal adnya pemisahan antara sains

\footnotetext{
${ }^{18}$ Omar Mohammad Al-Toumy Al-Syibany, Falsafah Pendidikan Islam, terj. Hasan langgulung (syah alam: HIZBI, 1991) h. 478

${ }^{19}$ Azyumardi Azra,dkk, Integrasi Keilmuan UIN Syarif Hidayatullah Jakarta Menuju Universitas Riset, (Jakarta : UIN Jakarta Press, 2006), h. 47.
} 
dengan agama. Karena penyatuan antara sistem-sistem pendidikan islam adalah tuntutan akidah islam. ${ }^{20}$

\section{c. Alasan Pengembangan Kurikulum}

Kurikulum merupakan salah satu instrumen atau komponen pokok untuk sebuah sistem pendidikan yang memiliki pengaruh sangat besar terhadap kualitas hasil pendidikan dan pembelajaran. Sehingga baik tidaknya hasil sebuah pendidikan banyak dipengaruhi oleh baik tidaknya kurikulum pendidikan yang dijalankan. Oleh karena itu peninjauan ulang atau revisi terhadap sebuah kurikulum mutlak dilakukan secara periodik dan berkesinambungan untuk pengembangan kurikulum agar sejalan dengan visi dan misi sebuah pendidikan dan relevan dengan perkembangan jaman.

Salah satu asas dalam pengembangan kurikulum adalah asas ilmu pengetahuan dan teknologi. Perkembangan IPTEK akan mempengaruhi perkembangan setiap individu, warga masyarakat, mempengaruhi pengetahuan, kecakapan, sikap, aspirasi, minat, semangat, kebiasaan dan bahkan pola-pola hidup mereka. ${ }^{21}$ Dengan IPTEK sebagai landasan, peserta didik diharapkan mampu mengikuti perkembangan ilmu pengetahuan dan teknologi dan kesenian sesuai dengan sistem nilai, kemanusiaan dan budaya bangsa.

\section{Kurikulum Pendidikan Islam Terpadu}

\section{a. Kurikulum Pendidikan Islam Menurut Ulama}

Undang-undang system pendidikan nasional no.20 tahun 2003 pasal 3 telah menegaskan bahwa tujuan pendidikan nasional adalah mengembangkan potensi peserta didik agar menjadi manusia yang beriman dan bertakwa kepada Tuhan Yang Maha Esa, berakhlak mulia, sehat, berilmu, cakap, kreatif, mandiri, dan menjadi warga

${ }^{20}$ Abudin Nata, dkk. Integrasi Ilmu Agama dan Ilmu Umum, (Ciputat: UIN Jakarta Press, 2003), Cet 1, h. 172.

21 Abdul Majid dan Dian Andayani, Pendidikan Agama Islam Berbasis Kompetensi, (Bandung: Remaja Rosda Karya, 2004), h.60. 
negara yang demokratis serta bertanggung jawab. Sejalan dengan itu, Syekh Khalid al-Hazimy berkata bahwa tujuan pendidikan adalah pengembangan bidang keilmuan, pembinaan akidah yang benar, pembinaan ibadah, pembinaan akhlak mulia, dan profesi hidup serta pembinaan jasmani.22 Beliau juga mengatakan bahwa pendidikan Islam memiliki beberapa keistimewaan dan karakteristik yang tidak ada pada pendidikan selain Islam. Diantara keistimewaan pendidikan Islam adalah rabbaniyah, lengkap, komprehensip dan terpadu, juga seimbang dan realistis. 23

Sayyid Sabiq menyatakan bahwa pendidikan Islam adalah upaya mempersiapkan anak dari segi jasmani, akal, dan rohani sehingga ia menjadi anggota masyarakat yang bermanfaat untuk dirinya maupun umat. ${ }^{24}$ Yusuf al-Qardawi menyatakan pendidikan Islam adalah sebagai pendidikan manusia seutuhnya, akal dan hatinya, rohani dan jasmaniyah, akhlak dan keterampilannya, dan menyiapkan untuk menghadapi masyarakat dengan segala kebaikan dan kejahatannya, manis dan pahitnya. ${ }^{25}$ Sementara Hasan Langgulung menyatakan bahwa pendidikan Islam adalah sebagai proses penyiapan generasi muda untuk menjadi peranan, memindahkan pengetahuan dan nilai-nilai Islam yang diselaraskan dengan fungsi manusia untuk beramal di dunia dan memetik hasilnya di akhirat.26

Dari pemaparan di atas, menunjukkan bahwa ulama Islam jelas mengatakan bahwa pendidikan Islam adalah pendidikan terpadu yang mencakup urusan dunia dan akhirat, pendidikan yang berorientasi kepada maslahat dunia dan maslahat akhirat. Dengan inilah maka kebahagiaan dunia dan akhirat dapat diraih dan dicapai sebagaimana doa yang senantiasa kita baca: "Ya Rabb kami, berilah

\footnotetext{
22 Khalid bin Hasan al-Hazimy, Ushul at-Tarbiyah al-Islamiyah, (Medinah: Darul Alam al-Kutub, 1420 H., h. 73.

23 lbid., h. 45-52.

${ }^{24}$ Sayyid Sabiq, Islamuna (Bairut: Dār al-Kutub al-'Arabi, t.th), h. 237.

${ }^{25}$ Yusuf al-Qardhawi, Pendidikan Islam dan Madrasah terjemahan Bustani A. Gani dan Zainal Ahmad (Jakarta: Bulan Bintang, 1980), h. 39.

${ }^{26}$ Hasan Langgulung, Beberapa Pemikiran tentang Pendidikan Islam (Bandung: al-Ma'arif, 1980), h. 94.
} 
kami kebahagiaan di dunia dan kebahagiaan di akhirat dan jauhkanlah kami dari siksa neraka”.

Dengan ini juga, manusia bias menjadi khalifah di permukaan bumi. Menjadi khalifah di atas bumi adalah merupakan fungsi dari manusia setelah diciptakan Allah yang bertujuan untuk mengabdi kepada Allah. ${ }^{27}$ Dengan khilafah ini jugalah kehidupan dunia akan tentram damai dan sejahtera karena diatur oleh manusia beriman, diatur dengan aturan Allah swt. yang sangat sempurna, tidak ada kekurangannya sama sekali.

\section{b. Kurikulum Pendidikan Islam dalam Alquran dan Sunnah}

Jika kita menelaah isi Alquran dan Sunnah, ternyata kita dapati kurikulum yang sempurna, kurikulum yang jauh dari dikotomi ilmu. Kita dapatkan bahwa di dalam keduanya terdapat nilai-nilai, norma dan aturan pendidikan Islam yang mengajarkan ajaran yang sangat agung dan indah, ajaran yang sempurna baik tentang nilai-nilai keagamaan atau akhirat maupun tentang keduniaan. Berikut ini sekilas tentang hal tersebut.

1) Ajaran terkait nilai-nilai akhirat

a) Ajaran akidah dan tauhid

Isi Al Qur'an secara keseluruhan hampir-hampir merupakan penetapan terhadap tauhid dan penafian dari lawannya yaitu syirik. Allah 'azza wa jalla menetapkan tauhid uluhiyah dan memurnikan ibadah hanya kepada Allah yang tidak ada sekutu baginya pada banyak ayat dalam Al Qur'an. Allah 'azza wa jalla juga mengabarkan bahwasanya seluruh utusan Allah menyerukan kepada kaumnya agar hanya menyembah Allah dan tidak menyekutukannya dengan sesuatu apapun. Sesungguhnya Allah 'azza wa jalla tidaklah menciptakan jin dan manusia kecuali untuk beribadah kepadaNya. Allah swt. berfirman:

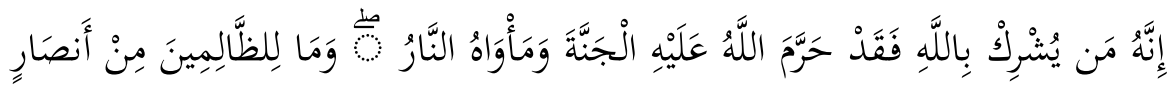

${ }^{27}$ QS. Az-Zariyat: 56. 
"Sesungguhnya orang-orang yang melakukan kesyirikan kepada Allah, niscaya Allah akan mengharamkan atasnya untuk bisa masuk surga dan tempatnya adalah neraka dan tidak ada penolong bagi orang-orang zhalim”. 28

b) Ajaran ibadah

Ajaran Islam menanamkan pada diri manusia keimanan yang benar dan pentingnya beribadah Allah swt. berfirman: "Dan tidaklah kuciptakan jin dan manusia kecuali untuk beribadah kepada-Ku".29 Ibadah dalam Islam memiliki makna yang luas, ia mencakup seluruh ucapan, perbuatan yang diridhai Allah swt. baik itu yang zhahir maupun yang batin.

c) Ajaran tentang takiyatun nufus

Tazkiyatun nufus adalah pensucian jiwa dari seluruh penyakit dan noda yang merusak jiwa manusia. Pensucian jiwa dalam Islam dilakukan dengan berbagai macam cara dan metode. Diantaranya adalah dengan:

i. Menghilangkan akhlak dan sifat tercela dari jiwa manusia

ii. Menghilangkan keyakinan-keyakinan yang menyimpang dari hati manusia seperti kesyirkan, bid'ah dan khurafat.

iii. Memperbanyak amal shalih dan kebaikan

2) Ajaran terkait nilai-nilai keduniaan

a) Ajaran tentang politik dan pemerintahan

Berikut ini beberapa contoh ayat dan hadis yang berkaitan dengan politik dan pemerintahan:

$$
\text { و أطيعوا الله وأطيعو ا الرسول وأولي الأمر منكم }
$$

"Dan taatilah Allah dan taatilah Rasul dan para pemimpin dari kalian" ${ }^{\prime 30}$

\footnotetext{
${ }^{28}$ QS. Al-Maidah : 72.

${ }^{30}$ QS. An-nisa: 59.
} 


$$
\text { لن يفلح القوم ولو ا امرهم امر أة }
$$

"Tidak akan berjaya satu kaum yang menyerahkan urusan mereka kepada seorang perempuan". ${ }^{31}$

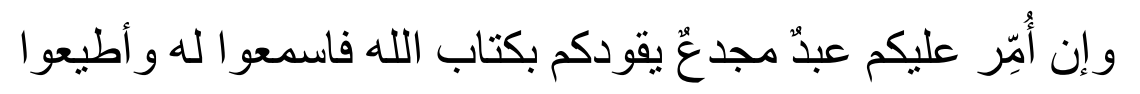

"Dan meskipun kalian dipimpin oleh budak hitam yang terputus hidungnya memimpin kalian dengan berhukum kepada Kitabullah maka hendaklah kalian dengarkan dan taati!"32
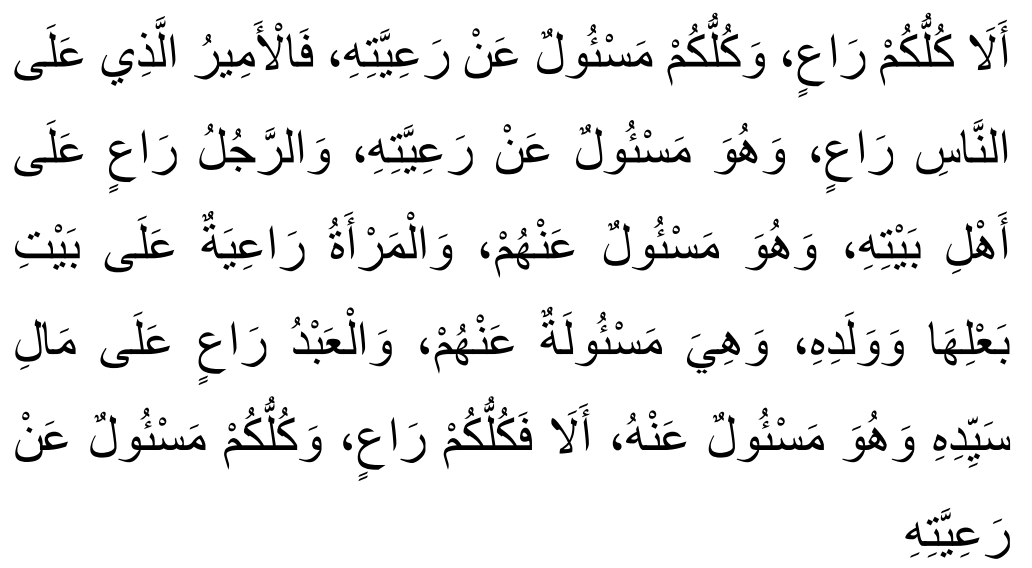

"Setiap kalian adalah pemimpin, dan setiap kalian akan dimintai pertanggungjawabannya. Seorang imam adalah pemimpin dan akan dimintai pertanggungjawabannya. Seorang laki-laki adalah pemimpin atas keluarganya dan ia akan dimintai pertanggungjawabannya. Seorang wanita adalah pemimpin atas rumah suaminya, dan ia pun akan dimintai pertanggungjawabannya. Seorang budak juga pemimpin atas harta tuannya dan ia juga akan dimintai pertanggungjawabannya. Sungguh setiap kalian adalah pemimpin dan setiap kalian akan dimintai pertanggungjawabannya".33

b) Ajaran tentang hukum dan pengadilan

${ }^{31}$ HR. Bukhari

32 HR. Muslim

${ }^{33}$ HR. Bukhari 


$$
\text { ومن لم يحكم بما انزل الله فأولئك هم الكافرون }
$$

"Dan barangsiapa yang tidak berhukum dengan apa yang Allah turunkan, maka mereka adalah orang-orang kafir ${ }^{234}$

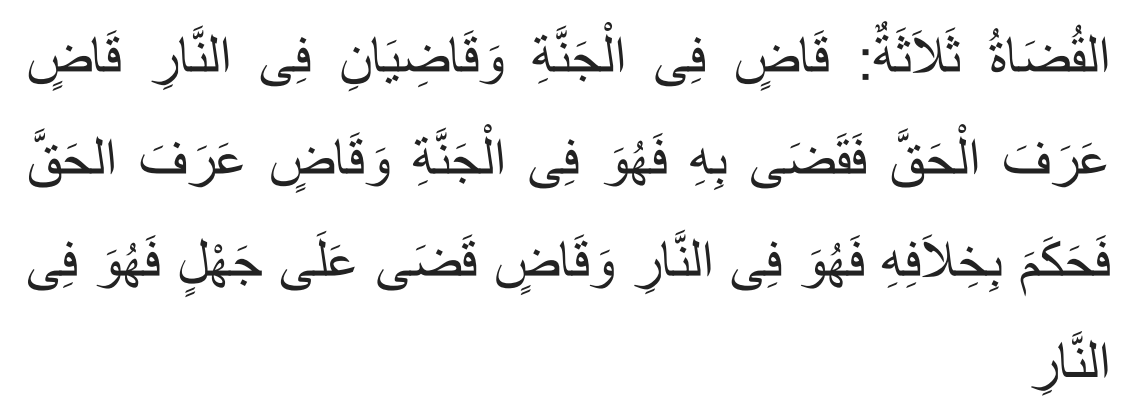

"Dari Ibnu Buraidah dari bapaknya dari Nabi saw., beliau bersabda, "Hakim ada tiga macam. Satu di surga dan dua di neraka. Hakim yang mengetahui kebenaran dan menetapkan hukum berdasarkan kebenaran itu maka ia masuk surga, hakim yang mengetahui kebanaran dan menetapkan hukum bertentangan dengan kebenaran ia masuk neraka, dan hakim yang menetapkan hukum dengan kebodohannya ia masuk neraka.",35

c) Ajaran akhlak

Diantara ayat Alquran yang mengajarkan tentang akhlak mulia

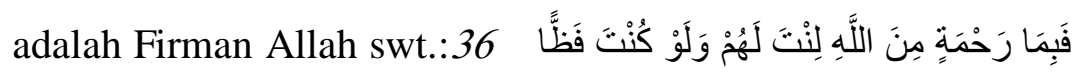
غَلِيظَ الْقَلْبِ لَانْفَضُوُ ا مِنْ حَوْلِكَ

"Maka dengan adanya rahmat Allah kamu telah berlemah lembut kepada mereka, sungguh jika kamu berlaku kasar dan bengis niscaya mereka akan lari darimu”.

Rasulullah saw. menegaskan bahwa beliau tidaklah diutus Allah swt. dan dingkat menjadi Nabi kecuali dalam rangka perbaikan akhlak manusia menuju akhlak mulia.

${ }^{34}$ QS. Al-Maidah: 44.

${ }^{35}$ HR. Abu Daud

${ }^{36}$ QS. Ali Imran: 159. 
d) Ajaran tentang kehidupan sosial, bermuamalah dan bermasyarakat

Selain hablum minallah, Islam juga mengajarkan hablum minan nas. Hablum minan nas adalah hubungan dan muamalah serta interaksi dengan manusia lain. Dalam agama Islam ajaran tentang itu sangat lengkap. Prinsip bermuamalah dalam Islam adalah tidak menyakiti orang lain, bersabar atas sikap buruk orang lain atas diri kita dan berbuat baik kepada orang lain. ${ }^{37}$

e) Ajaran tentang kehidupan yang mandiri dan bermartabat

Islam sebagai agama yang rahmatan lil alamin, mengajarkan kepada umatnya untuk menjadi manusia-manusia yang mandiri, tidak menjadi beban bagi orang lain, namun justru harus bisa membantu orang lain. Hal ini terlihat dari beberapa hal berikut:

1. Islam mengajarkan bagaimana etika bisnis dan perdagangan yang baik.

2. Islam memerintahkan umatnya untuk makan dari rezeki yang halal.

3. Melarang umatnya mengemis dan menjadi peminta-minta.

4. Menegaskan bahwa tangan yang di atas lebih baik dari tangan yang di bawah.

5. Menjelaskan bahwa para Nabi manusia paling mulia juga aktif bekerja mencari nafkah.

6. Para shahabat Nabi Muhammad saw. begitu juga para ulama mereka aktif bekerja mencari nafkah.

\section{c. Rekonstruksi Kurikulum Pendidikan Islam}

Diantara faktor keruntuhan masa kejayaan peradaban Islam (The golden age of Islam) adalah adanya dikotomisasi terhadap ilmu pengetahuan, artinya di kalangan umat Islam terjadi pembedaan yang

${ }^{37}$ Khalid, Ushul, h. 154. 
sangat tajam antara ilmu agama dan ilmu sains/IPTEK. Salah satu contoh dikotomi pendidikan Islam adalah seperti yang disebutkan dalam kitab Ta'limul Muta'alim yang banyak diajarkan di pesantren tradisional:

"Ilmu hakikatnya hanya ada 2, ilmu fiqih untuk kesempurnaan agama dan ilmu kedokteran untuk kesehatan jasmani/badan. Selain keduanya hanyalah hampa dan dinilai sebagai omong kosong belaka", ${ }^{38}$

Selain itu, penyebab kemunduran umat Islam adalah adanya keyakinan dari sebagian umat bahwa menuntut ilmu itu tidak penting, karena ilmu itu bisa didapat langsung dari Allah tanpa proses belajar, inilah yang mereka klaim sebagai ilmu laduni.

Perkembangan zaman yang multikompleks seharusnya disikapi dan dijawab dengan pengembangan kurikulum agar sesuai dengan perkembangan jaman dan kebutuhan masyarakat. Setidaknya 3 tahun sekali kurikulum harus direkonstruksi sesuai dengan kebutuhannya. Dalam merekonstruksi kurikulum, maka setiap sekolah idealnya wajib memberikan masukan yang bermanfaat terhadap kondisi yang terjadi dan berkembang dimana lembaga pendidikan itu berada. Misalkan saja; apabila terjadi krisis khatib, maka dalam pelajaran agama harus memasukkan kurikulum pengkaderan khatib. Begitu juga tentang bilal mayit, muazzin, dan hal-hal yang dianggap mulai berkurang di tengah-tengah masyarakat.

Pemberian jam pelajaran yang proporsional untuk pelajaran keagamaan terkait akidah dan ibadah dan jam pelajaran umum dalam setiap sekolah atau madrasah dirasa sangat perlu. Hal ini akan berdampak kepada perbaikan nilai-nilai ilmu umum dan ilmu agama bagi anak didik. Kedangkalan ilmu agama akan menyebabkan anak alergi terhadap agama, sebaliknya kedangkalan ilmu umum akan berdampak juga ketakutan untuk masuk ke jenjang pendidikan yang bermuatan ilmu umum. Namun apabila kesetaraan itu terlaksana, maka secara tidak langsung kurkulum akan mencetak pelajar-pelajar

${ }^{38}$ Burhanudin Az-zarmuji, Syarah kitab Ta'limul Muta'ali, h. 9. 
yang siap pakai dan faham tentang nilai-nilai agama (spritualisasi) dan kehidupan nyata (sekularitas).

\section{Simpulan}

Sebagai penutup, maka penulis ingin menyampaikan kesimpulan singkat dari makalah kami ini. Sekularitas adalah pemisahan antara urusan agama dan urusan keduniaan mencakup masalah politik, ekonomi, hukum, sosial-budaya serta ilmu pengetahuan dan teknologi. Sementara spritualitas adalah hal-hal yang berkaitan dengan kerohanian dan agama serta ketuhanan dan kehidupan akhirat. Pengembangan kurikulum agar sesuai dengan perkembangan jaman dan kebutuhan masyarakat maka setidaknya 3 tahun sekali kurikulum harus direkonstruksi sesuai dengan kebutuhannya. Dalam merekonstruksi kurikulum, maka setiap sekolah idealnya wajib memberikan masukan yang bermanfaat terhadap kondisi yang terjadi dan berkembang di mana lembaga pendidikan itu berada. Misalkan saja; apabila terjadi krisis khatib, maka dalam pelajaran agama harus memasukkan kurikulum pengkaderan khatib. Begitu juga tentang bilal mayit, muazzin, dan hal-hal yang dianggap mulai berkurang di tengah-tengah masyarakat. Pemberian jam pelajaran yang proporsional untuk pelajaran keagamaan terkait akidah dan ibadah dan jam pelajaran umum dalam setiap sekolah atau madrasah dirasa sangat perlu. Hal ini akan berdampak kepada perbaikan nilai-nilai ilmu umum dan ilmu agama bagi anak didik. Kedangkalan ilmu agama akan menyebabkan anak alergi terhadap agama, sebaliknya kedangkalan ilmu umum akan berdampak juga ketakutan untuk masuk ke jenjang pendidikan yang bermuatan ilmu umum. Namun apabila kesetaraan itu terlaksana, maka secara tidak langsung kurkulum akan mencetak pelajar-pelajar yang siap pakai dan faham tentang nilai-nilai agama (spritualisasi) dan kehidupan nyata (sekularitas). 


\section{Pustaka Acuan}

Alquran al-Karim

Abdullah, Abdurrahman Saleh, Teori-Teori Pendidikan Berdasarkan Al-Qur'an, Jakarta: PT Rineka Cipta, 2007.

al-Hazimy, Khalid bin Hasan, Ushul at-Tarbiyah al-Islamiyah, Medinah: Darul Alam al-Kutub, $1420 \mathrm{H}$.

al-Qardhawi, Yusuf, Pendidikan Islam dan Madrasah terjemahan Bustani A. Gani dan Zainal Ahmad, Jakarta: Bulan Bintang, 1980.

Al-Syibany, Omar Mohammad Al-Toumy, Falsafah Pendidikan Islam, terj. Hasan langgulung, Syah Alam: HIZBI, 1991.

Azra, Azyumardi,dkk, Integrasi Keilmuan UIN Syarif Hidayatullah Jakarta Menuju Universitas Riset, Jakarta : UIN Jakarta Press, 2006.

Hamid, Hamdani, Pengembangan Kurikulum Pendidikan, Bandung : Pustaka Setia, 2012.

Hawali, Safar, al-'Ilmaniyah, Mekah: Daru Makkah, 1982.

Langgulung, Hasan, Beberapa Pemikiran tentang Pendidikan Islam, Bandung: alMa'arif, 1980.

Ma'arif, Syamsul, Revitalisasi Pendidikan Islam, Yogyakarta : Graha Ilmu, 2007.

Majid, Abdul dan Dian Andayani, Pendidikan Agama Islam Berbasis Kompetensi, Bandung: Remaja Rosda Karya, 2004.

Nata, Abudin, dkk. Integrasi Ilmu Agama dan Ilmu Umum, Ciputat: UIN Jakarta Press, 2003.

Nata, Abuddin, Filsafat Pendidikan Islam, Jakarta: Logos Wacana Ilmu, 1997.

Nihaya, Filsafat Umum : dari Yunani sampai Modern, Makassar: Berkah Utami, 1999.

Praja, Juhaya S., Aliran-Aliran Filsafat dan Etika, Bogor : Kencana, 2003.

Pardoyo,.Sekularisasi Dalam Polemik, 1993.

Syukur, Amin, Sufi Healing, Terapi dengan Model Tasawuf, Jakarta : Erlangga, 2012.

Sabiq, Sayyid, Islamuna, Bairut: Dār al-Kutub al-‘Arabi, t.th. 
Tahir, M., Negara Hukum Suatu Tentang Prinsip-prinsipnya Dilihat dari Segi Hukum Islam, Implementasinya pada Periode Negara Madinah dan Masa Kini , Jakarta: Kencana Prenada Media Group, 2007..

Tafsir, Ahmad, Filsafat Pendidikan Islami: Integrasi Jasmani, Rohani dan Kalbu Memanusiakan Manusia, Bandung: Remaja Rosdakarya, 2006.

Tim Penyusun Kamus Pustaka Bahasa, Kamus Besar Bahasa Indonesia, Jakarta: Balai Pustaka, 2002. 